\title{
HAPPINESS AS AN OBJECTIVE OF SHARI'AH: ANALYSING ITS OPERATIONALISATION IN PUBLIC POLICY
}

\author{
Ahmad Badri Abdullah* \\ Wan Naim Wan Mansor**
}

\begin{abstract}
Research on happiness has generated much interest in recent years, largely due to the failure of many modern societies to offer a balanced and healthy lifestyle parallel to their rapid material growth. Research has shown that happiness is a more comprehensive indicator of public well-being compared to aggregate-based evaluations (such as GDP, household debt, and so forth). Happiness is also a more holistic and humane measure for informing policymaking decisions, and more likely produce better results. Surveys in Islamic jurisprudence have shown that happiness-in its contemporary conception-is absent from religio-legal mind-sets and considerations. Happiness is somehow overlooked in Islamic jurisprudence, despite numerous references to 'aspects' of happiness in the Qur'an and Islamic philosophical and mystical traditions under terms such as falāh, farḥah, sacādah, mutmainnah, hayātan tayyibah, masrūroh and sakīnah. This article proposes that happiness be recognised as one of the higher objectives (maqāșid al-'äliyyah) of Shari'ah. Its socioeconomic applications will also be highlighted. It is proposed that Islamic countries readjust their evaluative measures of development and elevate happiness as a core factor for consideration.
\end{abstract}

Keywords: happiness, maqāṣid al-sharī'ah, development, public policy

\section{Introduction}

Happiness is a contemporary concern, a postmodern bent, moving away from the materialism and industrialism which defined the age of modernism. Research on happiness and its applications in public policies is rapidly gaining global recognition. Under the auspices of the United Nations, a High Level Meeting was held in April 2, 2012 under the theme 'Wellbeing and Happiness: Defining a New Economic Paradigm'. In the wake of this meeting, the first World Happiness Report 2012 was released, since which four more World Happiness Reports have been published - the latest being the 2016 Update (a shorter interim version), with the more complete and special edition scheduled for 2017. ${ }^{1}$ State-level implementation of happiness, however, started way back in 1972, when Bhutan 
first coined the term Gross National Happiness (GNH), which it engraved onto its constitution. Since then, Bhutan has become the lead nation in officially implementing GNH as an alternative to the conventional aggregate-based Gross National Product (GDP). ${ }^{2}$ At the institutional level, the Harvard School of Public Policy recently (April 2016) received USD 21 million in research funds to launch its new Center for Health and Happiness. ${ }^{3}$

We clarify at the outset that in the context of this article 'happiness' does not denote 'hedonism', which is primarily engrossed in short-term pleasures and sensual gratification. Rather, 'happiness' as understood here is closer in meaning to the 'Eudemonia' of Aristotle, which emphasises overall relationship harmony and includes living well and doing well with oneself and others. ${ }^{4}$ We would also like to draw on Webster's online dictionary, which defines happiness as a state of well-being or contentment, a pleasurable or satisfying experience. ${ }^{5}$ From this, we can see that, from a linguistic perspective, the definition of happiness emphasises the subjective experience rather than observed actions (or evident choices), and as in, for example, conventional economics. The complexity and subjective nature of happiness in this context is also reminiscent of the culmination of Maslow's 'hierarchy of needs', which are 'self-actualising' or 'self-transcending' - a stage where basic physiological and psychological needs must first be met. Consequently, by directly tapping on the 'subjective experience' of individuals, we automatically get a general overview of their physical and psychological conditions. We would also like to divide happiness into two types: affective happiness and evaluative happiness. The former focuses on the short term, while the latter focuses on the overall reflective state. Balance between these two temporal factors is a key concern in happiness research, which translates into the very meaning of sustainability. In short, happiness research is a revolutionary development in measuring human well-being (whether in economics, public policy, and so forth), especially because it underscores holism and sustainability.

Surveys in Islamic jurisprudence however, show that happiness - in its contemporary conception - is absent from religio-legal considerations. Happiness is seemingly overlooked in legal ijtihād, despite many references to aspects of happiness in the Qur'an and Islamic philosophical and mystical traditions under terms such as farhah, falāh, sa 'ädah, mutmainnah, hayātan tayyibah, masrüroh and sakinah. But although 'happiness' is not a specific operating factor in Islamic law and jurisprudence, it is deeply embedded in the primary sources - the Qur'an and hadith. This article intends to make the case for happiness as one of the higher objectives (maqāssid al- 'äliyyah) of Shari'ah, while also highlighting its socio-economic benefits. In doing so, Islamic primary sources, the Qur'an and the prophetic traditions, and the works of key scholars (in particular that of Ibn 
Ashur) will be surveyed and analysed. We believe that happiness can be a strong candidate of maqūșid al- 'âliyyah. ${ }^{6}$

\section{Happiness in the Islamic Tradition: a Literature Review}

In the Islamic intellectual tradition, profound discussions have occurred on happiness in both the realms of philosophy and mysticism. The Islamic philosophical discourses on happiness are particularly interesting and noteworthy. Abu Nasr Muhammad al-Farabi (870-950 AH), for instance, regarded happiness as the ultimate goal of each individual, as well as the main purpose of ethics and education, to the extent that he even saw happiness as the reason for human existence. In light of this, happiness ( $s a^{\prime} \bar{a} d a h$ ) became the central theme of his political theory, the ultimate end towards which political life is supposedly oriented. For al-Farabi, happiness was benefit and all benefit was happiness. Happiness was the absolute good that should be desired for its own sake. He also claimed that anything which prevents the acquisition of happiness is a total evil. ${ }^{7}$ Furthermore, according to al-Farabi, happiness was an existential perfection, as well as the final end to which the soul, in all of its parts, works towards:

It became clear that among all good, happiness is the greatest good and among of all effective factors is the most complete end that every human effort is moving towards. ${ }^{8}$

For al-Farabi, the pursuit of happiness was therefore a rational endeavor, with happiness and morality being intricately related. Therefore, humans need to acquire rational knowledge when in pursuit of spirituality and the attainment of the ultimate goodness of perfect happiness. Nonetheless, according to alFarabi, in the pursuit of happiness, reason cannot work in isolation, since happiness is in fact a long progression involving all the other human faculties (i.e. nutritive functions, senses, imagination, appetites, moral inclinations, and the intellect). ${ }^{9}$ Likewise, it is necessary for those pursuing happiness to do so in the company of other human beings. Borrowing the Aristotelian concept of humans as social animals, al-Farabi contended that a legitimate political association is necessary for the achievement of happiness, that man's happiness is closely related to his political association.

Al-Farabi's characterisation of a political structure in which the whole community works together towards achieving the ultimate good (i.e. happiness) hints at the fact that material or worldly happiness is possible and deemed the first step towards an absolute, eternal happiness, attainable only by the soul when leaving the material body. To achieve this end, all community members must work in concert, to achieve happiness and self-realisation within the contexts of 
their own unique positions in society. Moreover, political leaders need to utilise their authority, power and means of persuasion to assist community members in the cultivation of their moral virtues; a moral and virtuous life is the sources of happiness for all community members.

Another renowned philosopher who wrote on the subject of happiness is Ahmad ibn Muhammad ibn Miskawayh (932-1030 AH). In his 'Book of Happiness' (kitāb al-sa 'âdah), Ibn Miskawayh elucidated that the levels of happiness vary according to the talents and abilities of each individual. $\mathrm{He}$ differentiated between the concept of 'goodness' and 'happiness', for goodness is a general condition of a community, whereas happiness implies the contingent state of each individual. ${ }^{11}$ Categorising happiness into different degrees, Ibn Miskawayh believed that man's happiness was possible in the worldly life and lay in the perfection of his spirit and body. ${ }^{12}$

Syed Muhammad Naquib al-Attas is a contemporary Muslim scholar who has philosophically explained the Islamic concept and experience of happiness, comparing it to the Western (both classical and modern) conception of the same term. He contends that happiness in the modern Western sense has been tainted by secularism, together with its moral and political crises. The Western version of happiness, which al-Attas coins the "modern conception of happiness," is, according to al-Attas, deprived of moral value and similar in nature to that of pagan societies. Moreover, the Western conception of happiness disregards the spiritual dimension of human life since the tradition merely identifies religion as one of the ever-changing cultural elements of society. For Al-Attas, Islam defines happiness as a genuine state of contentment, connected to the Creator. Such happiness brings peace to mind and spirit, and hence engenders wellbeing in life. Two essential sources of happiness in Islam, al-Attas suggests, are knowledge and virtue: knowing their Creator and being consciously aware that they are created to be His vicegerents, nurtures peace and happiness in their hearts. The Qur'an also provides a meaning of happiness in both worldly life and the hereafter, demonstrated by the term al-faläh, which means the well-being or success acquired through righteous deeds. This is evidently mentioned in the Qur'an, when Allah says: "Successful indeed are those who believe." Moreover, al-Attas identifies two levels of happiness, namely psychological and spiritual. While the first level is worldly in nature and can be categorised as feelings and emotions that arise when wants and needs are gained via noble values, the latter is permanent in nature and forms the basis of a temporary earthly life that leads to knowledge of Allah. ${ }^{13}$

The work of al-Ghazali entitled 'Kimiya al-Sa 'ādah' and Ibn al-Qayyim's 'al-Wabìl al-Sabīl min al-Kalām al-Tayyib' denote the mystical or spiritual dimension of happiness in the Islamic tradition. This particular genre of literature 
focuses primarily on the method of obtaining spiritual happiness. According to Ibn Qayyim, there are at least three tokens of the servant's happiness: when blessed, he is thankful; when tried, he perseveres; and when sinful, he seeks forgiveness. ${ }^{14}$ In the same vein, al-Ghazali suggests that happiness emanates from self-knowledge, i.e. from knowing that human beings, although granted souls that are perfect, become tainted by passion and desire. For al-Ghazali, each and every human is born with "knowing pain in the soul," resulting from a disconnection from the Ultimate Reality. The reason for man's unhappiness, alGhazali asserts, is his attempt to remove such pain through physical pleasure. For al-Ghazali, the prophets are those who have attained perfect happiness; normal people are only able to be happy in accordance with the degree to which they emulate those prophets. ${ }^{15}$

In summing up, it is plain that there is unanimous agreement among Muslim scholars, be it classical or contemporary, that Islam provides a holistic conception of happiness. Muslim scholars agree that happiness is attainable within the context of worldly life and while also being one of the prerequisites for eternal happiness in the afterlife. It is worth noting that happiness in the Islamic tradition, as proposed by al-Farabi, transcends individual life to include the public and political spheres.

Nevertheless, surveys in the field of Islamic legal discourse show that 'happiness' is not considered a part of the decision making factors in Islamic jurisprudence/ijtihād. Benefits, or mașlahah, are often vaguely termed as 'selfevident' benefits, such as being alive, orderliness, and peace. However, happiness could be regarded as an extension of mașlahah, since in each mașlahah happiness can be seen as the 'next step' or its 'higher goal'.

\section{Happiness as an Objective of the Shari'ah: A Preliminary Proposal}

This research attempts to propose that happiness become one of the objectives (maqșad) of Shari'ah. It will do so by providing evidence from the primary Islamic sources, i.e. the Qur'an and prophetic traditions, and by considering contemporary developments in maqūșid al-shar' 'ah as a discourse and the debate pertaining to its functional dimension. Surveying these factors will set the stage and lay the foundation for the newly proposed maqsad of happiness.

Maqāssid al-sharī'ah, as an Islamic legal concept, has undergone significant development throughout the course of intellectual history. This development has been marked by the introduction of new universal maqāșid or essentials (darūriyyāt) by a number of contemporary Muslim scholars and jurists. Rashid Rida for instance, identified reform (i.e. of the pillars of faith), reason, knowledge, wisdom, freedom, independence, socio-political-economic 
reform, and human rights as new maqāșid. ${ }^{16}$ Ibn Ashur proposed that the universal maqūșid of Shari'ah be orderliness, equality, freedom, facilitation, and preservation of the pure natural disposition (fitrah), ${ }^{17}$ while al-Qaradawi included preservation of true faith, human dignity and right, purification of the soul, restoration of moral values, good families, fair treatment of women and a strong Islamic nation. ${ }^{18}$ Kamali has added to this economic development, scientific exploration, world peace and fundamental constitutional rights. ${ }^{19}$ This expanding nature of contemporary maqāssid has brought new perspectives with regards to its role and function in society.

There is also an ongoing debate about whether maqāssid should be an independent branch of learning, or merely a subsection of ușül al-fiqh. Ibn Ashur was the first scholar to call for the establishment of an independent science of the intent and purpose of the Shari'ah:

If we want to lay down definitive and categorical principles for the understanding of the Shari'ah, we need to return to the traditionally accepted propositions of usul al-fiqh and reformulate them. We should critically evaluate them, rid them of the alien elements that crept into them, and supplement them with the results of thorough comprehension and careful thought. Then, we need to call it 'science of the higher objectives of the Shari'ah' ('ilm maqāșid al-sharī 'ah). In other words, we should leave the discipline of usul al-fiqh as it is, a source from which the methods of formulating legal argumentation could be derived. ${ }^{20}$

Al-Hasani, Ibn Ashur's commentator, brings the debate a step forward by proposing the establishment of maqāsisid as a totally independent science. In his work, he elucidates the detailed meaning of maqāssid together with its goal, subject matter, and methodology. ${ }^{21}$ In the quest for establishing happiness as a lone standing objective (maqșad) of Shari'ah, we believe it is time that maqāssid al-shar' 'ah be deemed an independent discipline, allowing it to play a broader role, not one confined to the boundaries of legal discourse.

For instance, maqāșid al-sharī'ah has currently made inroads into the discourse of development, a much broader and more significant role than merely functioning as a tool to revitalise $u s ̦ \bar{u} l$ al-fiqh. Umer Chapra has proposed that, in order to ensure the sustained development and well-being of society, the concept of 'safeguarding' (hifz) in the classical deliberation of maqāssid needs to be re-examined. What is necessary in the current context, he argues, is the continued enrichment of the primary objectives (maqassid al-asliyyah) of Shari'ah, as well as their corollaries (maquassid al-tab 'iyyah), in the pursuit of the continuous improvement of individuals and society. In 
all, Chapra introduces fourteen corollaries, encompassing dignity, justice, spiritual and moral uplift, security, freedom, education, good governance, removal of poverty, employment, equitable distribution of wealth, stable family life, social solidarity, minimisation of crime, peace and happiness. Interestingly, Chapra, suggests that happiness is the highest corollary objective, achieved by a community whenever the other thirteen objectives are duly satisfied. ${ }^{22}$

\section{Happiness in the Qur'an and the Prophetic Traditions}

Removal of grief (al-hazan) is a recurring theme in a number of Qur'anic verses and Prophetic traditions, imparting the understanding that sadness is a negative element in life and, by contrast, that happiness is a positive element. Thus, it is implied that happiness is one of the ultimate aims of believers, both in this world and in the hereafter. We now quote some Qur'anic verses which elucidate that removal of sadness or grief designates success for the believers:

Nay, whoever submits His whole self to Allah and is a doer of good, He will get his reward with his Lord; on such shall be no fear, nor shall they grieve. (Al-Baqarah, 2:112)

Those who believe, and do deeds of righteousness, and establish regular prayers and regular charity, will have their reward with their Lord: on them shall be no fear, nor shall they grieve. (Al-Baqarah, 2:277)

In the case of those who say, "Our Lord is Allah", and, further, stand straight and steadfast, the angels descend on them (from time to time): "Fear ye not!" (they suggest), "Nor grieve! but receive the Glad Tidings of the Garden (of Bliss), that which ye were promised." (Fussilat, 41:30)

Even though in the above verses the removal of grief most probably refers to the afterlife, it is evident that the Qur'an recognises worldly or psychological happiness. There is in fact a verse in which Allah terms the life which is led by the righteous believers, either male or female, as a 'good life':

Whosoever doeth right, whether male or female, and is a believer, him verily we shall quicken with good life, and We shall pay them a recompense in proportion to the best of what they used to do. (An-Nahl, 16:97) 
Even though there is a plethora of interpretations by different scholars about the meaning of 'good life' in this verse, it is interesting to note that Ibn Abbas, in a report attributed to him, contends that it simply implies happiness in the worldly life. ${ }^{23}$ Perhaps in support of this, there are indeed verses in the Qur'an that record events which prompted the believers to rejoice for various reasons, including receiving revealed knowledge and the countless bounties from Allah:

Those to whom We have given the Book rejoice at what hath been revealed unto thee. (Al-Ra' $\mathrm{d}, 13: 36$ )

In the bounty of Allah and in His Mercy - in that let them rejoice: that is better than the (wealth) they hoard. (Yunus, 10:58)

Within a few years, with Allah is the Decision, in the past and in the Future: on that Day shall the Believers rejoice. (Rum, 30:4)

In the abovementioned verse from Surah Rum, the believers cheered after the victory of the Romans over the Persian empire, due to their firm faith in revealed religion. It is also interesting to note that, in this particular verse, the Qur'an relates awareness of the global political situation with an overarching notion of happiness. In a hadith reported by Sa 'ad ibn Abi Waqqas, the Prophet (pbuh) said:

There are four things that are essential for happiness: a righteous wife, a spacious home, a good neighbour and a sound means of transportation. And there are four things that make one miserable: a bad neighbour, a bad wife, a small house and a bad means of transportation. ${ }^{24}$ (Narrated by Ibn Hibban in al-Sahihhah, no.1232)

This hadith corresponds with a verse in the Qur'an, in which it is pointed out that:

Beautified for mankind is love of the joys (that come) from women and offspring; and stored-up heaps of gold and silver, and horses branded (with their mark), and cattle and land. That is comfort of the life of the world. Allah! With Him is a more excellent abode. ('Ali 'Imran, 3:14)

It is interesting to note that the hadith's enumeration of the factors which make up happiness resonates well with the abovementioned corollary objectives proposed by Chapra, if they are viewed from a macro-level perspective. A righteous wife, for instance, denotes a stable family life; a spacious home 
denotes dignity, security and fair distribution of wealth; a good neighbour denotes social solidarity; and sound means of transportation (in the modern sense) could denote efficient infrastructure as a result of good governance. ${ }^{25}$

\section{Positioning Happiness in the Modern Maqāṣid Discourse}

In order to establish happiness as a maqșad, it is important to consider Ibn Ashur's method of utilising integral contemporary concerns. For instance, Ibn Ashur's deliberation on the objective of freedom (hurriyah) is at variance with the conventional Islamic conception of freedom ( $\mathrm{al}$ - 'itq) as discussed by classical jurists. Instead of referring to $a l$ - itq, which basically means release from slavery, Ibn Ashur introduced the term hurriyah, a newly-coined term in Islamic law that implies a broader definition, perhaps bearing similarities (as 'Auda argues) to the well-known Islamic concept of 'will' (mashi'ah). It is interesting that Ibn Ashur consciously attributed the term hurriyah to literature from the French revolution, translated into Arabic in the nineteenth century. This evidently shows that, according to Ibn Ashur's method, an integral contemporary concern could make inroads into the list of contemporary Islamic objectives - but, of course, with a strong basis in the Islamic primary sources. ${ }^{26}$ Certainly, Jamal al-Din al-Attiyyah proposes that the essentials (darüriyyāt) should be dynamic, capable of ever-adapting to the passage of time in order to be practical and relevant. ${ }^{27}$

Furthermore, analysing Ibn Ashur's deliberation on 'equality' as one of the maqāssid is important for establishing happiness as a valid Shari'ah objective. In his work, Ibn Ashur referred to the framework of the Six Essentials (darüriyyāt $a l$-sitt) as a basis for equality as a higher objective of Shari'ah. The basic equality enshrined in the contemporary notion of human rights are, he argued, guaranteed by the fundamentals of Islamic legislation: the Islamic emphasis on the equal right to existence is expressed, Ibn Ashur argues, by the human rightsassociated terms 'protection of life' and 'protection of progeny'; the equal right to the means of life is expressed by the term 'protection of property'; the equal right to live a proper and good life is expressed by 'protection of intellect' and 'protection of honor'; and, finally, the right to belong to a religious community (jamī'ah diniyyah) is expressed by 'protection of religion'. In other words, according to Ibn Ashur, equality, as one of the higher objectives (maqāṣid al'alliyah), is embodied within the six above-mentioned essentials. ${ }^{28}$

Likewise, happiness is intimately related to the Six Essentials - although in a slightly different way. For instance, protection of life, which involves living in secure and healthy conditions, is a necessity for a happy life; protection of progeny, which includes establishing a strong and harmonious family 
institution, could also bring about happiness; protection of property, which signifies possession of basic assets, such as house and transportation, could trigger happiness; protection of honour, which implies the preservation of an individual's dignity and privacy, is definitely a prerequisite of man's happiness; finally protection of religion, which involves methods for self-purification, is of course an essential aspect for a holistic concept of happiness. Therefore, the Six Essentials, it could be argued, serve as the means towards the achievement of happiness as the ultimate aim of human life.

In summing up, happiness should be deemed as one of the higher intents of the Shari'ah, along with other related intents, such as equality, freedom, and orderliness.

\section{The Awareness of Happiness as a Basis for National Development and Public Policies}

By introducing happiness as a sound objective of Shari'ah, this article will now attempt to explicate its functional dimension, specifically in the sphere of public policy and governance. As mentioned before, according to contemporary scholars, maqāsșid al-sharī ah, as a self-standing science, should play a significant role in prescribing a path for policy making and good governance. As far as happiness is concerned, there have been a number of global developments which reveal an emerging awareness and concern for the vital role this principle could play in underpinning the course of economic development and governance in order to achieve sustainable development. Even though this global happiness movement is currently initiated and led by non-Muslim countries, like Bhutan and the United Kingdom, Muslim countries should not be left out. By promoting happiness as an Islamic objective, this article will ultimately propose that Muslim countries need to learn lessons from those who have adopted happiness as a guiding principle in their public policies.

\section{The Role of Happiness in Socio-economic Evaluations}

An awareness of the limitations of Gross Domestic Product (GDP) as a measure of societal success first began to emerge in 1934 with Simon Kuznets, the economist who initially created the concept as an aid for the US Congress during the Great Depression. In one of his statements, he claimed that:

The welfare of a nation can scarcely be inferred from a measurement of national income. ${ }^{29}$ 
Some economists suggest that there are at least two major impediments associated with GDP: that it takes no account of sustainability or durability, and that it does not provide any information regarding income distribution.

In 2010, a group of world renowned economists, including Joseph Stiglitz, Amartya Sen, and Jean Paul Fitoussi, were commissioned by the then President of France, Nicolas Sarkozy, to write a report highlighting the insufficiency of GDP as a guide to public policy. In their report, they called on policy-makers to use more subjective measurements in the course of governing societies, including happiness metrics. ${ }^{30}$ Likewise, other research conducted by Diner, Lucas and Schimmack also suggested that happiness and well-being be recognised as new viable frameworks for public policies. ${ }^{31}$

A number of recent events on the global stage have also highlighted the urgency of applying happiness measurements for policy purposes. For instance, in the United Nations General Assembly 2011, Bhutan proposed a resolution to encourage governments to pursue additional measures so as to capture happiness and well-being in their development plans, as well as in guiding public policies, since GDP did not adequately reflect the holistic aspects of well-being and happiness in a country. ${ }^{32}$ In the same year, the European Union (EU) initiated the Bringing Alternative Indicators Into Policy (BRAINPOL) project. $^{33}$ In 2014, the project team published a final report focusing on labour markets and the green economy, whereby they suggested happiness, well-being, and other 'beyond GDP' indicators be recognised for specific policies. ${ }^{34}$

In the context of economics, happiness is a more holistic and humanistic measurement than GDP. It posits human beings, not as mere robots focused on yielding material results, but as individuals worthy of respect and dignity. Fittingly, Bruno S. Frey and Alois Stutzer-two leading economists in happiness research-have considered happiness to be the latest revolution in economics, capable of offering invaluable insights into, and better evaluations of, human well-being. ${ }^{35}$ This position is echoed by the UN World Happiness Report, establishing happiness as the "proper measure of social progress and the goal of public policy." 36 'Subjective' or 'revealed' measurements (contrasting with 'objective' or 'observed') offer a more nuanced solution compared to conventional aggregate-based measurements.

\section{Happiness and Political Institutions}

According to Frey and Stutzer, applying happiness research in the realm of political institutions serves a crucial role. It avoids treating people as "metric stations, ${ }^{\text {" }} 7$ reducing them to one-way 'machines' that merely respond to feeds 
of pre-determined input, such as money, utility or welfare. This purely economic approach assumes that humans are primarily 'recipients' of policies, rather than concomitant 'contributors' to policy-making decisions. The application of happiness research in the study of political institutions (e.g. type of political process, form of government, legal system, associations, etc.), addresses this predicament by operating on the basis that humans are decision-makers and will find satisfaction or happiness in exercising their decision-making abilities. Although from a certain perspective, pure economic maximisation of happiness does make sense, in reality it strips humans of their autonomy. Frey and Stutzer describe economic maximisation as exuding implicit and explicit tendencies towards "benevolent dictatorship," due to its heavy reliance on politicians to make welfare decisions instead of addressing the "rules of the game" (i.e. political institutions, political eco-system).$^{38}$

Having autonomy and the ability to make important decisions is a selfevident and fundamental right. Only by shifting focus away from individual politicians and focusing instead on institutions can the problem of "benevolent dictatorship" be mitigated. Consequently, there are two ways in which happiness research can benefit the study of political institutions and human well-being: ${ }^{39}$

\section{Identify the types of institutions that best enable people to meet their} preferences, thus providing them with the most happiness. The range of institutions analysed in this regard include self-binding mechanisms, social norms, private and public law (i.e. the rules of the game), as well as the constitutional conditions necessary to establish rules. In regards to 'procedural utility' or freedom to choose, research by Veenhoven came up with an interesting finding: poor countries, with generally low levels of education, value economic freedom more, while rich countries reported higher correlated subjective well-being associated with political freedom. ${ }^{40}$ For those who value political freedom more, democracy is the preferred institution due to its inherent feature of 'direct participation'. For example, a study of 24 Swiss cantons showed that direct democracy in the form of popular referenda significantly increased levels of happiness. ${ }^{41}$

2. Provide important informational feedback on specific policies: Happiness research provides important insights into the effects of policies, insights that are untapped by conventional methods (e.g. voting, referendum etc.). Some policy issues that have already benefitted from happiness research include: the effects of mandatory retirement (Charles 200442; Oreopoulos $2007^{43}$ ); the impact of tobacco taxes on smokers' well-being ${ }^{44}$ and the relation between working time regulations and people's well-being. ${ }^{45}$ 
The latter is especially useful in the context of cost-benefit analyses. Via happiness research, however, all these policies can be 'weighted' for their degree of effectiveness.

Applying happiness research in the realm of political institutions preserves and promotes the fundamental human right of democratic participation. It mitigates tendencies towards 'benevolent dictatorship', which rely too much on state actors and thereby reduce individual autonomy. It also avoids those questionable ethics which result from high-handedly treating humans as passive recipients, only concerned with being 'fed' and other benefits that will maximise their happiness. Also, compared to conventional economic measurements of well-being (i.e. aggregate-based), using subjective well-being as a measurement of happiness prevents (or lessens the ability) of politicians to 'tweak the numbers' or shift the aggregate-based goalposts to serve their own interests. Measurements based on subjective well-being are also more inclusive and more representative of society as they factor in the poor and marginalised, who are otherwise invisible in measurements relying on 'observed choices' due to their inability and incapability to make choices in the first place.

\section{Happiness and Economic Policy}

Happiness and its impact on the economy is of novel interest for economists due to the great progress in the measurement of utility developed in psychology. There are at least three economic determinants of happiness, namely employment, income, and inflation.

According to numerous research studies in different countries and time periods, individual experience of unemployment proves to be a significant factor in reducing happiness. Empirical research on happiness has shown that, even when receiving similar amounts of income when employed, jobless individuals are noticeably depressed and unhappy. At a broader level, people are also generally unhappy about rises in unemployment. This is even the case for those who hold a job. Their anxiety may be due to empathy (i.e. for the unemployed) or concern that they, themselves, will be unemployed in the future. They may also be anxious about the socio-economic ramifications of unemployment, such as increases in tax, interest-rates, crime-rates, social tension, and even violent protests. ${ }^{46}$

It is often assumed that there is a positive relationship between high income levels and happiness, the former increasing the latter. It is demonstrated, however, that richer countries do not necessarily make their people happier ad infinitum. Equally, when poor societies reach a subsistence level, happiness does 
not significantly increase with additional income. In other words, income and happiness may not be correlated. Certainly, Frey and Stutzer argue that, due to the 'adaptation' process, constant and repeated exposure to material possessions reduces their ability to produce happiness over time. Moreover, people tend to compare themselves to others with regards to income, consumption, and status, often looking up rather than down, producing a sense of inferiority. ${ }^{47}$

Inflation relates negatively with levels of happiness, i.e. increases in inflation strikingly reduce happiness levels in society. According to a study conducted in twelve European countries from 1975 to 1991, an increase of $5 \%$ in inflation reduced average happiness by 0.05 units of satisfaction. This means that, with higher inflation, $5 \%$ of the population shifted to a lower category of life satisfaction (i.e. from 'very satisfied' to 'fairly satisfied'). ${ }^{48}$ Moreover, it is commonly held that a $1.7 \%$ decrease in inflation increases unemployment by one percentage point. Therefore, if unemployment rates increase by $5 \%$, the inflation rate needs to be cut by $8.5 \%$ in order to dampen its effects on society. ${ }^{49}$

Since both unemployment and inflation are factors in producing happiness, a trade-off between the two needs to be determined in order to maintain life satisfaction in society.

\section{Happiness and Environmental Policy}

Research has shown that the natural environment has a positive effect on the well-being of humans. Natural and healthy environments contribute towards human well-being in three ways: ${ }^{50}(1)$ innate human response, (2) lower pollution levels detrimental to health, and (3) encouragement of other beneficial behaviours, such as physical exercise, recreation and social interaction.

Concerning the first aspect, there are "direct pathways" in our nervous system that correspond to the natural environment. Physiological effects of these pathways include stress reduction and restoration of attention. This innate affinity to nature is described as biophilia; work by Wilson, ${ }^{51}$ Falk and Balling, ${ }^{52}$ and $\mathrm{Han}^{53}$ suggests that this internal human disposition might be a product of biological adaptations resulting from beneficial interactions our human ancestors had with certain environments.

Concerning the second aspect, natural environments are less polluted than urban ones; they are places where the negative effects of noise and air pollution can be avoided. Such negative effects include low sleep quality, hearing impairment, and raised stress levels. The last of these could lead to other chronic diseases, such as coronary disease, stroke, immune system defects, and birth defects. ${ }^{54}$ 
Concerning the last aspect, the other two factors - innate biophilia and healthy conditions - make humans more at ease, relaxed, and focused in natural environments. This in turn encourages them to exercise and socialise. Studies by Barton, Pretty ${ }^{55}$ and Morris ${ }^{56}$ all corroborate this relationship.

The link between the natural environment and happiness can help inform both governmental and other policy-making institutions. For example, research conducted by George Mackerron and Susana Mourato, entitled "Happiness is Greater in Natural Environments," utilised a massive 1,138,481 responses from 21,947 UK respondents. ${ }^{57}$ This feat was achieved via an iPhone app called 'Mappiness', which randomly asked questions about momentary wellbeing while keeping track of respondents' GPS locations (i.e. to check on whether they were within the vicinity of a natural or urban environment). This research, and the continued utilisation of 'Mappiness', then informed the UK National Ecosystem Assessment (NEA) in their measurement of the impact of environmental interventions and/or environmental disasters/hazards on momentary well-being. The investigated environmental interventions included the creation of a new woodland, the cleanup of a contaminated site, the introduction of a community conservation programme, and the start of a green exercise programme. Disasters and hazards, on the other hand, included oil spills, forest fires, epidemics, water and soil contamination, and floods. ${ }^{58}$

Bhutan, famous for its Gross National Happiness, also considers the environment to be one of the primary determinants of happiness. Bhutan currently maintains $72 \%$ of its land under forest cover, while constitutionally required to maintain only $62 \% .{ }^{59}$ During climate negotiations at the climate Conference of Parties (COP) 21 held in Paris, Bhutan not only renewed its pledge to remain carbon neutral, but proposed plans to become 'carbon negative' in the near future. ${ }^{60}$

Whereas the impact of the natural environment on human well-being was previously unclear, happiness research enables environmental policies to be measured more precisely and in an objective manner, thus enabling more effective and efficient policy-making.

\section{Conclusion \& Policy Recommendations}

The foregoing discussion has surveyed both the Islamic primary sources and the wider body of Muslim scholarly literature on the conception of happiness. Evidently, all the relevant sources have much to say about happiness and its promotion. From the perspective of contemporary maquassid discourse, establishing happiness as a maqsad closely emulates Ibn Ashur's approach to equality. This method yielded encouraging results, showing that happiness 
manifests itself within all of the Six Essentials (al-daruriyah al-sittah). As such, this article argued that happiness could become a higher goal of the Shari'ah.

At the operational level, however, it is interesting to see whether Islamic principles directly agree with the current, scientifically-based conclusions of happiness research. This article argues that they do - that Islamic principles and teachings corroborate the findings and conclusions of happiness research. Given this, below are some operational precepts that would underpin the maqsad of happiness:

1. Developing a balanced worldview: People with personality traits prizing material goods higher than other values "tend to be substantially less happy." ${ }^{61}$ Islam emphasises spiritual awareness, faith in God and the afterlife above and beyond material property. The Qur'an clearly states that worldly possessions, by themselves, will not grant us true happiness.

2. Promoting reflection and gratitude: 'Relative income' factors (i.e. people comparing themselves with others) is another determinant of unhappiness. ${ }^{62}$ At the personal level, this matter receives much attention via Islamic concepts like syukur (gratitude) and qana'ah (contentment). The renowned Prophetic hadith, "Look at those who are beneath you and do not look at those who are above you, for it is more suitable that you should not consider as less the blessing of Allah," ${ }^{63}$ also supports the message of contentment. On the other hand, at the societal level, Shariah enshrines the importance of income distribution and social justice without privilege or discrimination, with much evidence in the sources about this (Cf., Q. al-Hashr, 59:7).

3. Enhancement of social trust and harmony: an adequate level of social trust and harmony is another important factor of happiness that can impact positively on other aspects of social life. ${ }^{64}$ Islam inculcates the practice of numerous periodic actions that could help foster trust and bonding within society, such as daily prayer congregations, weekly Juma 'ah prayers, biannual eid gatherings, the Hajj pilgrimage and charity.

4. Preservation and enhancement of the environment: Access to a natural, clean environment is found to positively foster happiness and improve well-being. ${ }^{65}$ Taking care of the environment is also fundamental to Islam. The relationship Islam posits between man and the environment is encapsulated within the core Islamic principles of tawhìd (oneness of being), khiläfah (man's responsibility as trustee of the earth), and the concept of sustainability guided by mizān and wașatiyyah. 


\section{Empowering individual autonomy and participation in the economic,} social and political realms: Higher 'procedural utility', or freedom to make important life decisions ${ }^{66}$ correlates significantly with higher levels of wellbeing and life satisfaction. This important value is greatly supported in the Qur'an, as demonstrated in its many verses outlining humanity's right to contemplate, choose, and make decisions for itself. Examples: Q. al-Shams, 91:8, Q. Fussilat 41:46, Q. al-Baqarah, 2:256, Q. al-Ma'idah, 5:48.

Therefore, this article suggests the following policy recommendations:

- Happiness is a strong candidate to be a part of the maqāsid al-sharī ah. At the conceptual level, happiness is deeply rooted in the Islamic primary sources, as well as in the Islamic intellectual tradition, which advocates happiness as an important aspect of human well-being. In fact, all the maqāșid al-sharīah, including the six essentials, are geared towards human well-being in both this world and the hereafter.

- Establishing happiness as a maqșad would introduce a new dimension to the understanding of maqāssid al-sharī $a h$, and could encourage religious and legal research that strikes closer to the intentions of Shari'ah. Also, current findings and conclusions in contemporary happiness research are compellingly corroborated by the Islamic sources. This means that advancements in happiness research can be adopted and integrated into Shariah-based policies (siyāsah al-shar 'iyyah).

- From a local perspective, the recently launched Malaysian Shariah Index, which uses maquassid al-shari 'ah as its core measuring principle, can expand its scope and dimensions by including the maqșad of happiness as a strong indicator of good governance.

- It is proposed that Islamic countries should re-adjust their evaluative measures for development by adding happiness as a core factor and criterion. Joining the global happiness movement should therefore be considered an Islamic purpose that merits both individual and societal commitment.

\section{Notes}

* Ahmad Badri bin Abdullah is Research Fellow at IAIS Malaysia, with a focus on maqasid al-shari'ah (the higher objective of Shari'ah), usul al-figh, and contemporary Islamic jurisprudence discourse. He is pursuing his $\mathrm{PhD}$ in the study of maslahah. He can be contacted at badri@iais.org.my.

** Wan Naim Wan Mansor is Analyst at IAIS Malaysia. He may be reached at wannaim@iais.org.my. 
1. United Nation, UN World Happiness Report 2016, John Helliwell, Richard Layard \& Jeffrey Sachs (eds.), 3, available online at http://worldhappiness. report/ed/2016/ (accessed on 18 June 2016).

2. Prahlad Shekhawat, Policy Innovations - Redefining Progress, available online at http://www.policyinnovations.org/ideas/briefings/data/000098/:pf_printable (accessed on 18 June 2016).

3. LKK Health Products Group, New Lee Kum Sheung Center for Health and Happiness Established at Harvard's Public Health School, available online at: http://www.prnewswire.com/news-releases/new-lee-kum-sheung-center-forhealth-and-happiness-established-at-harvards-public-health-school-300255973. html (accessed on 22 April 2016) https://www.hsph.harvard.edu/news/pressreleases/health-and-happiness-center/

4. See Julia Annas, The Morality of Happiness, (New York \& Oxford: Oxford University Press, 1993), 330, see also Musikanski, L. "Happiness in Public Policy" Journal of Social Change, 6(1), (2014), p. 5.

5. See Merriam Webster Online dictionary, available online at http://www.merriamwebster.com/dictionary/happiness, (accessed on 13 April 2016).

6. In his work, Ibn Ashur differentiate between two categories of maqāșid: immediate intents (maqāṣid al-qarībah) and higher intents (maqāṣid al'äliyyah): "If, on the other hand, they are universal, we refer them as immediate intents (maqāșid al-qarībah), such as the preservation of the faculty of reason; and if they are higher universals, we refer to them as higher intents (maqasșid al- 'aliyyah), of which there two types; sources of benefit, and sources of harm." Gamal el-Din Attia explicates that the higher intents coined by Ibn Ashur comprise innate human understanding, benevolence, rights, equality and freedom. See Gamal el-Din Attia, Towards Realisation of The Higher Intents of Islamic Law: Maqāșid al-Sharī ah: A Functional Approach, Nancy Roberts (trans.), (London \& Washington: IIIT, 2006), p. 101.

7. Hamideh Behrouz Moghaddam, “Happiness and Muslim Philosophers’ Attitudes About It Investigation of The Theories of Five Muslim Philosophers (al-Farābi, Miskawayh, Nașīr, Naraqi, and Shebra) about Happiness" Cumhuriyet University Science Journal, v.36, no.3, Special Issue (2015), 2787.

8. Abu al-Nasr al-Farābi, Risālah Al-Tanbīh 'ala Sabīl al-Sa 'ādah, Subhān Khalīāt (ed.), ('Ammān: Mansyūrāt al-Jamī' ah al-Idariyyāh, 1987), p. 47-8.

9. Wanderley Dias da Silva, Al-Farābi’s Idea of Happiness in the Perfect State, (unpublished article), p. 3.

10. Ibid, p. 7.

11. Ibrahim Abu Bakar, "Some Aspects of Ibn Miskawayh's Thought" Islamiyyet, v. 10, (1989), p. 120-1.

12. Hamid Reza Alavi, "Ethical Views of Ibn Miskawayh and Aquinas" Philosophical Papers and Review, v. 1 no.4 (May, 2009), p. 3.

13. Syed Muhammad Naquib al-Attas, The Meaning and Experience of Happiness in Islam, (Kuala Lumpur: International Institute of Islamic Thought \& Civilisation, 1993), See also Rahimah Hamdan \& Shaiful Bahri Md. Radzi, "In Search of Happiness in a Malay Hero's Life" International Journal of Humanities and Social Sciences, v. 4, no. 6(1) (April, 2014), p. 135-6.

14. Ibn al-Qayyim al-Jawziyyah, The Invocation of God (al-Wābīl al-Sayyīb min 
al-Kalām al-Tayyīb), M. Abdurrahman Fitzgerald \& Youssef Slitine (trans). (United Kingdom: Islamic Text Society, 2000), p. 2.

15. See Abu Hamid al-Ghazālī, The Alchemy of Happiness, Claud Field \& Elton I. Daniel (trans. \& ed.), (London: M.E. Sharpe, 1991), pp. 15-9.

16. See Muhammad Rashīd Ridhā, al-Wah̄̄ al-Mohammad̄̄: Thubūt al-Nubuwwah bi al-Qur'an (Cairo: Mu'assasah 'Izz al-Dīn, n.d.), p. 100.

17. Cf. Muhammad al-Tāhir Ibn 'Āshūr, Ibn 'Āshūr's Treatise on the Higher Objectives, p. 183.

18. Yusuf al-Qaraḍawī, Kayfa Nata 'āmal ma 'a al-Qur'ān al- 'Az̄ìm, (Cairo: Dār alShurūq, 1999), p. 75-96.

19. Mohamad Hashim Kamali, Principles of Islamic Jurisprudence, (Cambridge: Islamic Text Society, 2003), 402, see also Mohamad Hashim Kamali, "Maqasid al-Shari'ah and Ijtihad as Instruments of Civilisational Renewal," Islam and Civilisational Renewal, v. 2, no. 2 (January, 2011), p. 267.

20. Cf. Muhammad al-Tāhir Ibn 'Āshūr, Ibn 'Āshūr's Treatise on the Higher Objectives, XXII.

21. See Ismail al-Hasani, Nazariyyah al-Maqasid inda al-Imam Muhammad alTahir ibn Ashur, (London: The International Institute of Islamic Thought, 1995), 98-120, p. 425.

22. M. Umer Chapra, The Islamic Vision of Development in the Light of Maqāsid alShari ' $a h$, (Jeddah, Islamic Research and Training Institute, Islamic Development Bank, 2008), p. 6, p. 9, p. 26.

23. Ismail ibn Umar Ibn Kathir, Tafsir al-Qur'an al-Azim, Sami ibn Muhammad alSalamah (ed.), (Riyadh: Dar al-Taybah, 2002), v. 4, p. 602.

24. Muhammad Nasīr al-Dīn Al-Albāni, Silsilah al-Ahādith al-Saḥ̄hah, (Riyadh: Maktabah al-Ma'arif, 1995), v.1, no.282, p. 509.

25. Cf., M. Umer Chapra, The Islamic Vision of Development, p. 10-25.

26. See Jasser Audah, Maqāșid al-Sharī 'ah as Philosophy of Islamic Law: A Systems Approach, (Virginia \& London: IIIT, 2008), p. 6.

27. Cf., Gamal el-Din Attia, Towards Realisation of The Higher Intents.

28. Cf. Muhammad al-Tāhir Ibn 'Āshūr, Ibn 'Āshūr's Treatise on the Higher Objectives, p. 143.

29. Simon Kuznets, "National Income, 1929-1932" 73 ${ }^{\text {rd }}$ US Congress, 2d session, Senate Document no. 124, (1934), p. 7.

30. Stiglitz, J., Sen, A. \& Fitoussi. J. P. (2009, September). Report by the Commission on the Measurement of Economic Performance and Social Progress. Available online at http://www.stiglitzsen-fitoussi.fr/documents/rapport_anglais.pdf (accessed on 26 May 2016)

31. Justin Fox, The Economics of Well-Being, available online on https://hbr. org/2012/01/the-economics-of-well-being (accessed on 12 May 2016).

32. UN News Center, Happiness should have greater role in development policy - UN Member States, available online at: http://www.un.org/apps/news/story. asp?NewsID=39084\#.V3qhCIdIibI(accessed on 10 June 2016).

33. Whitby, A., BRAINPOL Project final report: Beyond GDP - From measurement to politics and policy. BRAINPOL deliverable 5.2. A collaborative programme funded by the European Union's Seventh Programme for research, technological development and demonstration under grant agreement No. 283024. World 
Future Council. Cited in Musikanski, L., "Happiness in Public Policy", p. 57.

34. Ibid.

35. Frey, B. S., \& Stutzer, A.. The Economics of Happiness. World Economics, v. 3, no. 1, (2002), p. 3.

36. United Nations. (2016). World Happiness Report 2016 Update.

37. Stutzer, A., \& Frey, B. S., Happiness and Political Institutions. DICE Report, v. 8, no. $4,(2010)$, p. 33.

38. Ibid, 33, see also Benjamin Radcliff, A Happy State: Why Is The Welfare Under Attack When Happiness Economics Shows It Is The System Most Conducive to Human Wellbeing, available online at https://aeon.co/essays/which-politicalsystem-does-happiness-economics-support (accessed on 30 June 2016).

39. Ibid, p. 35.

40. Veenhoven, Ruut, "Freedom and Happiness: A Comparative Study in Forty-four Nations in the Early 1990s", Ed. Diener and Eunkook M. Suh (eds.), Culture and Subjective Well-Being, (Cambridge, MA: MIT Press, 2000), pp. 257-88.

41. Frey, B. S., \& Stutzer, A., "The Economics of Happiness" World Economics, v. 3 , no. 1, (2002), pp. 1-17.

42. Charles, K. K., "Is Retirement Depressing? Labor Force Inactivity and Psychological Well-Being in Later Life", S. W. Polachek, (ed.), Accounting for Worker Well-Being. Research in Labour Economics, (Elsevier, Amsterdam, 2004), v. 23, pp. 269-99.

43. Oreopoulos, P., "Do Dsdropouts Drop out Too Soon? Wealth, Health, and Happiness from Compulsory Schooling", Journal of Public Economics, v. 91 (2007), pp. 2213-29.

44. Gruber, J.H. and S. Mullainathan, "Do Cigarette Taxes Make Smokers Happier?", Advances in Economic Analysis and Policy, v. 5, no.1, (2005), pp. 1-43. Cited in Stutzer, A., \& Frey, B. S. (2010). Happiness and Political Institutions.

45. Alesina, A., E. Glaeser and B. Sacerdote, "Work and Leisure in the United States and Europe: Why So Different?", M. Gertler and K. Rogoff, (eds.), NBER Macroeconomics Annual 2005, (MIT Press, Cambridge), Mass., pp. 1-64. Cited in Stutzer, A., \& Frey, B. S., "Happiness and Political Institutions".

46. Bruno S. Frey \& Alois Stutzer, "What Can Economists Learn from Happiness Research?" Journal of Economic Literature, v. xl, (June, 2002), pp. 402-35.

47. Ibid,

48. See Tella, R.D. et al., "Preference Over Inflation and Unemployment" The American Economic Review, v. 9, no. 1, (March, 2001), p. 338.

49. Cf., See Tella, R.D. et al., "Preference Over Inflation and Unemployment", 340.

50. George Mackerron and Susana Mourato "Happiness is Greater in Natural Environments" Global Environmental Change, v. 23, no. 5 (October 2013), p. 994.

51. Wilson, E. O., "Biophilia and the Conservation Ethic", S. R. Kellert \& E. O. Wilson (eds.), The Biophilia Hypothesis (Washington DC: Island Press, 1993), pp. 31-4.

52. Falk, J. H. \& Balling, J. D., "Evolutionary Influence on Human Landscape Preference," Environment and Behavior, v. 42, no. 4), (2010), pp. 479-93.

53. See Han, K., "Responses to Six Major Terrestrial Biomes in Terms of Scenic Beauty, Preference, and Restorativeness" (sic) Environment and Behavior, v. 39, 
no. 4, (2007), pp. 529-56

54. Cf., George Mackerron and Susana Mourato "Happiness is Greater in Natural Environments", p. 2.

55. Barton, J. \& Pretty, J., "Urban Ecology and Human Health and Wellbeing,", K. Gaston (ed.), Urban Ecology, (Cambridge: Cambridge University Press, 2010), pp. 202-29.

56. Morris, N., "Health, Well being and Open Space: Literature review," OPENspace, available online at http://www.openspace.eca.ac.uk/pdf/healthwellbeing.pdf (accessed on 6 June 2016).

57. Cf. George Mackerron and Susana Mourato, "Happiness is Greater in Natural Environments", p. 5.

58. Ibid, p. 14.

59. Antonia Gawel, 4 Lessons from Bhutan on the Pursuit of Happiness above GDP, available online at https:/www.weforum.org/agenda/2016/05/4-lessons-frombhutan-on-the-pursuit-of-happiness-above-gdp/ (accessed on 20 June 2016).

60. Ibid.

61. Frey, B. S., \& Stutzer, A., "The Economics of Happiness" World Economics, v.3, no.1, (2002), pp. 1-17.

62. Ibid; see also UN World Happiness Report 2016 Update.

63. Sahih Muslim, v.1, hadith no. 467, Sunan Ibn Majah, Book. 37, hadith no. 4281.

64. Cf., UN World Happiness Report 2012, p. 70.

65. Cf., George Mackerron and Susana Mourato, "Happiness is Greater in Natural Environments", p. 994.

66. Cf., UN World Happiness Report 2012, p. 65. 